\title{
HULDE AAN ONS OU VERTALERS
}

\author{
H.F. van Rooy, Dept. Semitiese Tale, PU vir CHO
}

\section{ABSTRACT}

The author presents a survey of the men involved in the Afrikaans translations of the Bible, stretching from the earliest efforts to 1979. In the first section he presents the translators: J.D. du Toit, H.C.M. Fourie, B.B. Keet, J.D. Kestell, E.E. van Rooyen.

In the subsequent section he deals critically with the choice of source texts and comments on the final choices for both the Old and New Testaments. He also evaluates lexicographical materials used in the various translations.

In conclusion, he presents, as an example, four translations, ranging from the State ("Statevertaling") to the new 7979 translation of Psalm 128.

Na vyftig jaar kan 'n mens nie anders nie as om te sê: Hoe kon hulle dit reggekry het! Die Rektor van die Grey-Universiteitskollege (vandag die Universiteit van die Oranje-Vrystaat) tree af om voltyds aan die vertaling van die Nuwe Testament te werk - op die ouderdom van 73. Die Teologiese Skool van die Gereformeerde Kerk staan een van sy twee professore af om die Ou Testament te vertaal. Die Kweekskool op Stellenbosch staan Iwee van sy vier professore af, in die tyd van die kerkstryd rondom prof. I. du Plessis. Vir die eerste keer kan die drie Afrikaanse Kerke hulle verskille vergeet om saam te werk aan 'n vertaling van die Bybel, wat op die Afrikaanse taal, die Afrikaanse kerke, die Afrikanervolk 'n stempel gelaat het, vyftig jaar lank reeds. Hierdie vertaling het 'ons Bybel' geword, die Woord van God in 'ons taal'. Wanneer daar gekyk word na die manne wat die werk gedoen het, die materiaal wat hulle gehad het - en nie gehad het nie - en die produk wat hulle gelewer het, dan pas dit om 'n wyle stil te staan met: "Dankie".

\section{DIE MANNE}

In die geskiedenis van die Afrikaanse Bybelvertaling tot 1933 word gewoonlik drie tydperke onderskei: van Pannevis tot die dood van S.J. du Toit in 1911: van 1914 at tot met die verskyning van die proefvertaling van die Evangelies en P'sulums in 1922 en van 1923 tot 1933, mel die verskyning van die volledige Bybel in Afrikaans (Nienaber en Heyl, 1961: 6,7). Hierby sou in die geskiedenis van die Bybel in Afrikaans tans nog Iwee periodes bygevoeg $k$ an word, naamlik die hersiening van die 1933-vertaling tot 1953 en die oorgaan tot die nuwe vertaling volgens dinamies ekwivalente model, wat tans volicoiing nader. Hier gaalı dit om die manne van die derde tydperk, waar as eindvertalers J.D. du Toit,

Koers, 48(2) 1983 


\section{Van Rooy}

H.C.M Fourie, B.B. Keet, J.D. Kestell en E.E. van Rooyen gedien het. In daardie tyd is die tekort aan toegeruste arbeiders meermale aangevoel. Dit was in die tweede tydperk een van die redes deur J.D. du Toit aangevoer waarom die Nederlandse Statevertaling bloot verafrikaans moet word en nie tot 'n nuwe vertaling uil die grondtale oorgegaan moes word nie (Du Toit, 1916: 2-3). Hierdie tekort aan toegeruste manne blyk goed uit 'n vergelyking van die personeelposisie aan teologiese inrigtings van die drie Afrikaanse Kerke in 1923, toe met die vertaling uit die grondtale begin is, en in 1976, toe die werk aan die nuwe vertaling reeds in volle gang was. Aan die Kweekskool op Stellenbosch was daar in 1923 vier professore, onder wie die eindvertalers Keet en Van Rooyen, en teologiese opleiding vir die NG Kerk in Pretoria nog meer as ' $n$ dekade in die toekoms. In $\mathbf{1 9 7 6}$ was daar in Stellenbosch sewe professore en vyf ander dosente en in Pretoria ses professore en nog twee ander dosente. Die Teologiese Fakulteit in Pretoria wat predikante vir die Hervormde kerk oplei, het in 1923 twee professore gehad teen ses en nog 'n dosent in 1976. Ook die Teologiese Skool op Potchefstroom het in 1923 twee professore gehad. In 1976 was daar agt. Altesame was daar dus agt teologiese professore van die drie Afrikaanse Kerke in 1923 teenoor vyf en dertig in 1976 - sonder om dosente van UNISA by te reken. Uit daardie agt moes drie as eindvertalers optree, J.D. du Toit, B.B. Keet en E.E. van Rooyen. Die ander twee was dr. H.C.M. Fourie, wat deurgaans sy werk as predikant moes doen, J.D. Kestell, wat in 1923 Rektor van Grey-Universiteitskollege was. Kortliks volg iets oor elkeen van die vyl eindvertalers, sodat by die hulde aan die vyf hulle nie maar net name van vyftig jaar gelede is nie. Die basiese gegewens is telkens ontleen aan die bronne vermeld aan die einde van die gedeelte oor elke vertaler.

\section{J.D. du Toit}

Jacob Daniel du Toił is op 21 Februarie 1877 in die Paarl gebore en op 1 Julie 1953 oorlede. Sy vader was ds. S.J. du Toit, een van die baanbrekers ten opsigte van die vertaling van die Bybel in Afrikaans. Na voltooing van sy studie a an die Teologiese Skool van die Gereformeerde Kerk op Burgersdorp was hy 'n kort tydjie veldprediker tydens die Iweede Vryheidsoorlog. Daarna studeer hy aan die Vrije Universiteit van Amsterdam en promoveer in 1903. Van 1903 tot 1911 was hy predikant op Potchefstroom en sedert 1911 prolessor aan die Teologiese Skool op Potchefstroom, waar hy tot 1949 in verskillende stadiums betrokke was by die onderrig van al die teologiese dissiplines sowel as Hebreeus. Saam met prof. F. Postma moet hy as grondlegger van die PU vir $\mathrm{CHO}$ gereken word. Benewens teoloog en Bybelvertaler was hy'n digter met 'n belangrike rol in die cerste opbloei van die Afrikaanse poësie. Ook sy beryming van die Psalms was 'n belangrike bydrae tot Afrikaans, veral in die kerke. Hy was een van die drie eindvertalers van die Ou Testament (Dekker en De Villiers, 1977). 
Hulde aan ou vertalers

\section{H.C.M. Fourie}

Hermanus Cornelius Marthinus Fourie is in 1882 in die distrik Carolina gebore en op 5 Augustus 1939 oorlede. Hy was die eerste van die eindvertalers wat oorlede is - en die een wat die jongste was by sy dood. Sy vader, I.C. Fourie, was 'n Boeregeneraal wat in die Tweede Vryheidsoorlog gesneuwel hel. Self het Fourie in sowel die Tweede Vryheidsoorlog as die Rebellie van 1914 geveg. In die Rebellie was hy 'n kommandant van die rebelle en is hy self gewond. Na die Rebellie was hy meer as ' $n$ jaar in die gevangenis. Hy het aan die Universiteit van Utrecht gestudeer en het sy doktorale eksamen in 1911 voltooi. In 1921 het hy in die Godsdiensgeskiedenis gepromoveer. Hy was predikant van die Hervormde kerk op Bronkhortspruit (1911-24), Johannesburg (1924-30) en Groot-Marico (1930-39). Hy was nederig van persoon maar tog baie beslis. Eersgenoemde blyk uit sy weiering om in 1912 ' $n$ benoeming as teologiese professor te aanvaar en lasgenoemde uit sy weiering om in die tweede periode saam te werk aan die verafrikaansing van die Statebybel, wat op die proefvertaling van 1922 uitgeloop het (Engelbrecht, 1940 en Dreyer, 1939). Oor sy bydrae tot die vertaling van die Ou Testament het J.D. du Toit (1939: 20) gesê. "Fk kan my nie voorstel hoe die groot werk sonder hom so gou sy voltooing sou bereik het nie".

\section{B.B Keet}

Barend Bartholomeus Keet is op 20 Junie 1885 op Alice gebore en oorlede op 21 Junie 1975. Hy was die jongste van die Bybelvertalers en die een wat die oudste geword het. Hy het gestudeer aan die Kweekskool op Stellenbosch, die Universiteit van Princeton en die Vrije Universiteit van Amsterdam, wadr hy in 1913 onder Herman Bavinck gepromoveer het. Hy was predikant in die NG Kerk Noorder-Paarl (1914-16) en Graff-Reinett (1916-19). Van 1920 to 1959 was hy professor aan die Kweekskool op Siellenbosch. Hy was die tweede eindvertaler van die Nuwe Testament en die enigste van die vyf eindvertalers wat tot met die hersiening van die vertaling in 1953 daarmee besig kon bly. Hy was 'n vurige kampvegter vir Afrikaans in die kerklike lewe toe Hollands nog 'kerktaal' was (Möller, 1974: Verhoef, 1977 en Jaarboek van die NG Kerke, 1975).

\section{I.D. Kestell}

John Daniel Kestell is in Pietermaritzburg gebore op 15 Februarie 1854 en oorlede in Bloemfontein op 9 Februarie 1941. Hy was die oudste van die vyf eindvertalers - reeds 79 by die verskyning van die Bybel in Afrikaans in 1933. $\mathrm{Hy}$ is in 1881 gelegitimeer en het as predikant die volgende NG Kerke bedien: 


\section{Van Rooy}

Du Toitspan (1881-2), Kimberley (1882-1893), Harrismith (1894-1903), Ficksburg (1903-12) en Bloemfontein (1912-19). In 1919 en 1920 was hy hoofredakteur van 'Die Kerkbode' en van September 1920 tot September 1927 Reklor van die Cirey-Universiteitskollege. As 'Vader Kestell' het hy 'n besondere posisie onder die Afrikanervolk ingeneem, onder andere weens sy betrokkenheid in die Tweede Vryheidsoorlog as lid van die Vrystaatse Driemanskap saam met president M.I. Steyn en generaal C.R. de Wet, sy bydrae tot die opheffing van die Afrikaner na die oorlog, sy rol in die Helpmekaarbeweging en sy groot bydrae tot die Bybelvertaling. Hy was een van die twee eindvertalers van die Nuwe Testament, met die leeue-aandeel in die vertaling daarvan (Nienaber, 1968).

\section{E.E van Rooyen}

Esias Fngelbertus van Rooyen is op Oudtshoorn gebore op 18 Maart 1881 en oorlede. ook op Oudtshoorn op 12 September 1951. Hy is op Desember 1909 tot die bediening in die NG Kerk toegelaat. In 1911 slaag hy in die doktorale eksamen aan die Vrije Universiteit van Amsterdam en het in 1916 daar gepromoveer. As predikant het hy in die NG Kerk Montagu (1911-14) en die Nuwe Kerk, Kaapstad (1916-20) bedien. Van 5 Mei 1920 tol 21 Junie 1950 was hy professor in Ou Testament aan die Kweekskool op Stellenbosch. Hy was een van die eindvertalers van die Ou Testament (Smit, 1981).

\section{DIE MATERIAAL}

'n Vergelyking van die posisie ten opsigte van materiaal waarvan by Bybelvertaling gebruik gemaak kan word vandag en sestig jaar gelede, toon duidelik die geweldige ontwikkeling in die vertaalkunde die afgelope aantal dekades. Dit geld ten opsigte van die basiese materiaal soos die teks waarop die vertaling berus, en leksikografiese materiaal en ook ten opsigte van die leoreliese besinning oor vertaling in die algemeen en Bybelvertaling en die besonder.

Wat die teks van die Nuwe Testament in die besonder betref, bied die verhandeling van C.J.C. Jordaan 'n volledige beeld. Dit is goed bekend dat die Bybelvertalers doelbewus vir die Textus receptus gekies het, uitgaande van die (foutiewe) gedagte dat dit die grondteks van die Statevertaling was (Jordaan, 1975: 17 en 60-62). Hierdie besluit is op 7 Augustus 1924 geneem, toe besluit is om na die kritiek teen die proefvertaling uit die grondtale te vertaal en nie meer bloot die Statebybel te verafrikaans nie (Nienaber, 1934: 118). Hierdie besluit om die Texlus receptus te gebruik - wat vandag sekerlik nie meer aanvaar sou word nie - het reeds in die tyd van die vertaling ernstige kritiek ontlok. So skryl C.F. Kies (1935: 8) dat hierdie besluit die vernaamste fout 
Hulde aan ou vertalers

by die vertaling was. Hierdie besluit was duidelik ' $n$ kompromie tussen twee standpunte: die verafrikaansing van die Statevertaling en vertaling uit die grondtale. Die Statevertaling het naas die grondtale die swaarste gewig gedra (Jordaan, 1975: 16-17: Weiss 1958: 157). Daar was wel kritiese uitgawes van die Nuwe Testament op daardie tydstip beskikbaar - groter uitgawes soos die van Tischendorf, Von Soden en Wescolt en Hort en kleiner uitgawes soos die van Souter en Nestle (Greenlee, 1967: 76, 77, 93 en 94). Veral laasgenoemde kan beoordeel word as die belangrikste alternatief vir die Textus receplus wat in die tyd van die Afrikaanse Bybelvertaling in die oog moes kom. Tog is doelbewus vir die Textus receptus gekies, met die vrces dat 'n vertaling gebaseer op die destydse kritiese teks nie aanvaarbaar sou wees vir mense wat met die Statevertaling grootgeword het nie. Hierdie standpunt is gehandhaaf ten spyte van besware uit verskeie kringe (Jordaan, 1975: 18-28). Vyf en iwintig jaar na die verskyning van die vertaling het die laaste oorlewende lid van die eindvertalers nog steeds volgehou dat die geesdriftige ontvangs van die vertaling deels aan die tekskeuse te danke was (Keet, 1958: 9).

Wat die teks van die Ou Test ament betref, is besluit om die Massoretiese teks te gebruik. Die teks wat gebruik is, was na alle waarskynlikheid die tweede uitgawe van Rudolf Kittel se Biblia Hebraica. Die derde uitgawe het eers vollerlig in 1973 (en geen gedeelte voor 1929 toe die vertalingswerk self in 'n groot mate reeds voltooi was) verskyn en is gebaseer op die codex loningradensis (1319 $\mathrm{A}$ ), terwyl die ecrste twee uitgawes gebaseer was op die tweede Rabbynse Bylx.l van lac ob ben Chayyim, uitgegee deur Daniel Bomberg in Venesië in 15245 Würthwein, 1979: 37). Würthwein noem hierdie leks die laat-Middelereuse I $x$ xtus recepxus (1979: 37). Dieselfde tipe besware - van kleiner omvang wel - kan teen hierdie teks geopper word as teen die lextus receptus. Dasir was egter nie ' $n$ ander uitgawe van beter gehalte beskikbaar nie, anders as in die geval van die Nuwe Testament, en daarom het hierdie keuse geen kritick tot gevolg gehad nie.

Ten opsigte van sowel Ou as Nuwe Testament is daar sedert 1933 op die gebied van lekskritiek geweldige vordering gemaak. Die teksuitgawe wat deesdae feitlik orals vir die vertaling van die Nuwe Testament gebruik word, is die derde uitgawe van die United Bible Socicties, wat in 1975 verskyn het. Hierdie teks is opgestel juis met Bybelvertaling voor oë en is nie 'n volledige kritiese uitgawe nie (Aland, 1975: V, IX). As verdere tekskritiese hulpmiddel is daar 'n gepaardgaande tekskritiese kommentaar uitgegee, wat verdere toeligting gee ten opsigte van die gedeeltes wat by vertaling tekskritiese aandag behoort te geniet (Metzger, 1971). Die derde uitgawe van Killel en Biblia Hebraica is intussen ook opgevolg deur die Biblia Hebraica Stultgartensia, wat in 1977 volledig verskyn het. Dit is op dieselfde manuskrip as die Billia Heb- 


\section{Van Rooy}

ralc a ${ }^{3}$ gebaseer en toon veral 'n groot verbetering ten opsigte van die tekskritiese dantekeninge en die adnbieding van die massoretiese dantekeninge. Alhoewel data nog nie 'n volledige kritiese uilgawe van die Ou Testament is nie - 'n projek in lst del het nog nie le veel gepubliseer nie - , hel die United Bit.'e Societies wel 'n voorlopige verslag oor hulle tekskritiese projek oor die Ou lestament gepubliseer, in vyl dik volumes tussen 1975 en 1980. Daar kan dus sonder teëspraak gekonstaleer word dat Bybelvertalers vandag baje beter dadraan toe is as voor $19331 \mathrm{ln}$ opsigte van sowel van die Ou Teslament as tekskulliese mighing

Wat leksikografiese materialal betref, is dit moeilik om met sekerheid te sê presies vall waller woordeboek en sells grammatikas die vertalers gebruik gemalak het. Len opsigte van die: Ou Jestament het dil sekerlik werke ingeslutt soos C;esenius-Kaulse h se: grammalika en die woordeboek van Brown, Driver en Briggs, lerwyl dadır ook wel ander woordeboeke beskikbaar was, meermale soos Brown, Diver en Briggs op die werk van Gesenius gethaseer. Ten opsigte van die Nuwe-Teslamentiese Grieks was daar die woordeboeke van Ihayes (1846) en veral die belangrike werk van Erwin Preuschen. wat in 1910 verskyn hel (Arnde en Gingrich, 1974: V). Ook hier was daar mererdere woordeboeke, ook vall Klassicke Grieks beskikbadr. Die giammatik. vall Islass, veIwork deur Debrunner se vierde uilgawe, het in 1913 verskyn, met die: vyfile in 1921, sodat ook hierdie werk moontlik gebruik is, soos ook die grammatika vall Moulton. By hierdie kort lys sou inderdaad baite ander mounllike werke gevoeg kon word, sonder om heeltemal seker te wees wat plosie" ge(butuik is. Dall vershillende sodanige werke gebruik is, blyk uit 'n brief van Kostell dan Lu Toit in 1924 (Nienaber en Heyl, 1961: 46).

Ook op hierdie gebied her daar sedert 1933 belangrike hulpmiddels verskyn, warsonder Bybolvertalers vandag nie meer sal wil werk nie, soos die groot loologiese woordeboek van die Nuwe Testament, bekend in die omgang as killel, wadlvaln die corsle aflewering in 1935 verskyn het, die Theologisches Begriffs loxicrom /lin) nouen Iestameril, wat tussen 1967 en 1971 verskyn het. Albej hicerdic werke wat op dic Nuwe Testament betrekking het, is ook in Engels vertad. Wat die Ou Testament betref, is in 1970 'n begin gemaak met dic publikasic: van 'n Theologisches Worterbuch onder leiding van Botterweck en Ringgren, waldrvall drie volumes reeds verskyn het, uit waarskynlik in fin ale ses. H liendie werk word ook in Engels vertaal. 'n Theologisches Handwörterbuch in twee volumes versorg deur Jenni en Westermann het in 1971 en 1976 verskyn.

Voor 1933 was tekste, grammatikas en woordeboeke, benewens kommentare vir die verskillende hoeke van die Bybel, die enigste middele tot beskikking 
Hulde aan ou vertalers

van vertalers. Vandag is daar ander uitnemende middele beskikbaar (Groenewald, 1969: 196). Hieronder kan vermeld word 'n tydskrif. The Bible (ramslator, wat sedert 1950 deur die United Bible Societies uitgegee word, waarin praktiese en teoretiese sake van belang by Bybelvertaling behandel word, asook ander literatuur wat deur die UBS uitgegee word, soos reeds sestien volumes in die reeks Transhator's handbooks en ses in die reeks Translator's guides, waarin vertaalprobleme in spesificke Bybelboeke bespreck word, monografieë oor plante en diere van die Bybel, Ou-Testamentiese aanhalings in die Nuwe Testament en selfs oor die voorbereiding van manuskripte deur vertalers. Veral die teorie van vertaling - waaraan voor 1933 weinig aandag gegee is $-k r y$ vandag baie aandag. Dink maar aan die baie publikasies van Nida oor hierdie onderwerp. Verskillende denkrigtings oor Bybelvertaling sal ook onderskei kan word, terwyl daar voor 1933 bloot maar tussen letterlike en vrye vertaling onderskei is. sonder werklik indringende besinning daaroor. Die vertalers van $1933 \mathrm{her}$ hulle in hulle vertaling deur die metode van die Statevertalers lat lci, soos blyk uit die hele uiteensetting wat Du Toit oor die metode gegee het (Nienaber, 1934: 120-127). Daaruil blyk wel dat daar besinning oor die metode was, met 'n keuse wat vandag nic oral aanvaar sal word nie, maar wat in terme van die tyd waarin dit geneerm is, tog verstaanbaar is.

Om die vertaling van 1933 te gaan mert met die beginsels van die dinamiesekwivalente vertaling, is nie altyd billik nie. Die ontwikkelinge sedert 1913 het wel 'n nuwe vertaling nodig gemaak. Die ontwikkeling was veral op vier terreine: Afrikaans en die Afrikaanse Taalwetenskap: die Anticke Taal- en Kultuurwetenskap, Tekskritiek en die Vertalwetenskap (Groenewald, 1969: 195). Tog het dit geen streep deur die vertaling van 1933 getrek nie. Terwyl die nuwe vertaling op ander vertaalbeginseds berus, kan die ou vertaling (soos hersien) en die nuwe mekaar pragtig aanvul om saam die Woord van God te laat spreek. Die vertalers van 1933 het ook nooil die vertaling as 'n linale vertaling gesien nie maar het self in 1934 met in hersiening van die vertaling begin (Nienaber en Heyl, 1961: 68). Wanneer 'n oordeel nor hulle werk gevel word, moet dit gedoen word met inagneming van die beperkinge waaronder hulle gewerk het.

\section{DIE PRODUK}

Oor die vertaling van 1933 het die voorsilter van die vertalingskommissic van die nuwe Afrikaanse vertaling gesê: "Die Afrikaanse Bybelvertaling word gereken onder die heel bestes wat in die eerste helfte van ons eeu verskyn het" (Groenewald, 1969: 196). Die geesdriftige ontvangs van die vertaling in sy tyd kan sonder verdere kwalifikasic as met 'vreugde en ontroering' bestempel 


\section{Van Rooy}

word (Nienabar en lleyl, 1961: 63). Ddar word selfs gesê dat die Bybel nie tydiger as in 1933 kon verskyn het nie, as dit gesien word teen die agtergrond van die depressie, droogte en verarming van die Afrikaner juis in daardie tyd (Grocenewald, 1970: 212). Na vyl en twintig jadr kon geoordeel word dat hierdic vertaling deur die Atrikaner alanvadr en lot sy eie gemaak is (Weiss, 1958: 154).

Wannerer 'n vertaling as vertaling geervalueer word, kan vier matalstawwe dangelé word, nl. die gechomdernherid an die oorspronklike teks, die suiwerheid van die: volksldal. vershldantidarleeid en kunswadrde (Groenewald, 1970: 215). Aan die erersle madstal voldoen die vertaling in hoé mate. Gesien teen die vertaslmolode kin sells gene word dat dit te vas is aan die teks, en die keuse vall die lextus recreptus as leks vir die Nuwe Testament bly 'n beswaar (Groenew.lld, 1970: 215). Die verialers het hulle nie vryhede met die laks veroorloof nic:. Die suiwerheid van die volkstaal het wel oncler die gebondenheid an die Slatevertaling gely, mar log kan hierdie aspe-k sells vesortretlik fenocm word (Groenewald, 1970, 216). Verstaanbaarheidl is 'n aspock wall soms nadelig geralak word deur 'n lellerlike vertaaliegniek (Liroenewald, 1970: 218), madr log het een van die heftigste kritici teen die tekskeuse van die? I ('xlus re'roprus gesè dat die vertaling vlot en gemaklik lees (D) Plessis, 1929: 248 - oor die proelvertaling van 1929). Die kunswaarde van die verbaling word baic hoog aangoslaan (Groenewald, 1970: 218). 'n Voorbeeld hiervan is die praghige alliterasie in Psalm 32: 9: "Wees nie soos 'n perd, soos 'n inuilresel wal geen verstand het nie, wat 'n mens moet tem met loom en level as sy lung, andirs kom hy nie naby jou nie". Alhoewel dit 'n letterlike vertaling is, hoef dir nog nie onalrikadans genoem te word ne. (Groenewald, 1969: 201,2).

Op die Afrikaduse isal self het die vertaling 'n positiewe invloed gehad. Die onlwikkeling in Afrikadus is een van die motiverings vir 'n nuwe vertaling, maar die vertaling vall 1933 hel self 'n invloed op hierdie ontwikkeling gehad (Weiss, 1958: 154). Dit kan nog steeds as 'n hoogtepunt in die geskiedenis van die Afrikaanse tad brestempel word (Groenewald, 1970: 212). Die vertalers het sleeds gewerk onder die be'sef dat hulle eintlik besig is om 'n godsdienstaal vir die Afrikaner te skep) (Ke.et, 1958: 9). In hierdie verband moet dadr ouk nie te negatie:f geoordecel word oor die doelbewuste ansluiting van die oorsetting by dic Statevertaling nie. Een van die beginsels in moderne Bybelvertaling is dat daar rekening gehou moet word met die tradisie waarin die vertaling sy plek moet inneem, met die "piêteit wat reeds rondom 'n bepaakde vertaling opgebou is" (Van Z.yl, 1967: 405). Hierdie (moderne) beginsel het in bepalende rol grespecol in die slyl en tekskeuse van die 1933-vertaling. Du Toit het die aansluiting by die Statevertaling met twee sake gemotiveer, $\mathrm{nl}$. dat 
Hulde aan on vertalers

die Statevertaling die gesaghebbende vertaling onder die Afrikaner was en dat die woorde en klanke daarvan by die volk geliefd was (Nirnaler, 1934: 121).

in Verdere belangrike winspunt van die vertaling is dat dit die ecrste brolungrike saak was wadrvan die drie Arikdanse Kerke met hant en siol sammerwerk het. In 1958 het die lasste oorlewende cindverialer dit soos volg pested: "In daardie grootse taak is die skeidslyne envourlig vergeet" (Keel, 1958: 8). Dieselfde gesindheid word tans weer by die nuwe vertaling ondervind.

Met 'n enkele voorbeeld word ten slotte die vertaling van 1933 self die geleentheid gebied om vir homself to getuig, in vergelyking net in pian ander vertalings. As vooreeld volg $\mathrm{n}$ kort Psalm 128, eers in die Statcvertaling, dan in die proefvertaing van 1922, wat uil die thatevertaling gemadk is, ddantla in die 1933-vertaling en ten slotte in die nuwe vertaing van 1979.

\section{STATEVERTALING}

\section{EEN lied Hammaälôth}

Wrigelukzalig is een eigelijk, die den HITRI vreest, die in zijne wegen wandelt:

2. Want gij zult eten den aboid uwer handrn: welgolukzalig zull gij rijn. en het zal u welgaan.

3. Uwe huisvrouw zal wezen als een viuchfluale wijnstok aan de zijden van uw huis, uwe kinderen als oliffplanten rondom uwe tafel.

4. Ziet, alzoo zal zekerlijk die man groggend worden, die den HILRE vreest.

5. De HEERE zal u zegen uit Zion, en gij zult her goede van Ieruzalom aanschouwen al de dagen uws levens:

6. En gij zull uwe kindskinderen tien. Vrede over Israel!

\section{2-VERT ALING}

\section{'n Lied Hammaälóth}

Welgeluksalig is 'n ieder wat dic IIIRL vrees, wat in Sy weë wandel:

2. want u sal eet die arbeid van u hande: wolgeluksalig sal u wees, en dit sal $u$ welgaan.

3. U huisvrou sal wees soos 'n vrughare wronstok aan die kant van u huis, " kinders soos olyfplante rondom 11 tafel.

4. Siet, so sal sekerlik die man gesein word wat die III RF vrees. 


\section{Van Rooy}

5. Die HERE sal u seèn uit Sion, en u sal die goeie van Jerusalem aanskou, al die dae van $u$ lewe.

6. en u sal u kindskinders sien. Vrede oor Israel.

[. e regstreekse aansluiting van hierdie vertaling by die Statevertaling is met die eerste oogopslag duidelik. Dit geld dinge soos die Hammaälôth, wat nie vertaal word nie, die woorde welgeluksalig in vers 1 en 2 , welgaan in vers 2 , huisvrou en kant van u huis in 3, siet in 4 en kindskinderen in 6 . ' $n$ Afwyking is die indikatiewe in verse 5 en 6 teenoor die optatiewe in die Statevertaling.

\section{3-VERTALING}

\section{'n Bederaartslied}

Welgeluksalig is elkeen wat die HERE vrees, wat in sy weë wandel!

2. Die opbrings van jou hande sal jy sekerlik eet: gelukkig is jy, en dit gaan met jou goed.

3. Jou vrou is soos 'n vrugbare wingerdstok binne-in jou huis, jou kinders soos olyiboompies rondom jou tafel.

4. Kyk, so sal sekerlik geseën word die man wat die HERE vrees.

5. Mag die HERE jou seën uit Sion, dat jy die voorspoed van Jerusalem mag aanskou al die dae van jou lewel

6. En dat jy jou kindskinders mag aanskou! Vrede vir Israel.

Dit is dadelik opvallend dat hierdie vertaling vlotter lees as die vorige. Onafrikaanse uitdrukkings in die vorige het verdwyn, soos ieder - elkeen, welgaan - goed gaan, huisvrou - vrou en siet - kyk. Verder is die opskrif vertaal. Die aansluiting by die Statevertaling kan nog steeds gesien word in uitdrukkings soos welgeluksalig in vers 1 - maar nie in vers 2 nie, waar dieselfde Hebreeuse uitdrukking mel "gelukkig is jy" vertaal is - en "kindskinders" in vers 6. Wat egter veral opvallend is, is die drie plekke war hierdie vertaling sterker van die Statevertaling afwyk. In vers 3 is die vrou nie meer "aan die kant" van die huis nie, maar "binne-in". Die Hebreeuse woord hier ter sprake (yarketê) dui meermale op 'n posisie aan die kant van iets, maar hier eerder op 'n plek in iets, soos ten opsigte van hierdie vers gestel deur Brown, Driver en Briggs (1974: 438), een van die werke wat baie waarskynlik op die lessenaar van die vertaler was! In vers 2 word die partikel $k i$ deur die Statevertaling en die 1922-vertaling redegewend vertaal, terwyl die waarskynliker eerder bevestigend vertaal moet word - daarom "sekerlik" in die 1933-vertaling. In vers 5 en 6 word 'n baie tipiese Hebreeuse konstruksie aangetref, waar 'n jussief opgevolg word deur ' $n$ imperatief en die imperatief die doel of gevolg van die jussief uitdruk. Die vorm van die jussief aan die begin van vers 5 is dieselfde as die van die imperfeklum, wat verklaar hoekom die Statevertaling dit met 'n 


\section{Hulde aan ou vertalers}

indikatief vertaal, met verder in die vertaling nie ' $n$ aanduiding dat die daaropvolgende optatiewe uit die voorafgaande voortvloei nie. Die 1933-vertaling se wens aan die begin van vers 5 met die daaropvolgende gevolgsinne is dus presies in die kol - en in ooreenstemming met 'n opmerking van Gesenius-KautschCowley daaroor (par. 110. i)! Hierdie standaardgrammatika was sekerlik op die vertaler se lessenaar! In hierdie kort Psalm kan dus iets gesien word van die presiesheid en oorspronklikheid van die 1933-vertaling.

1979-VERTALING

\section{'n Pelgrimslied}

Dit gaan goed met elkeen wat die Here dien en sy wil doen.

2. Die vrug van jou arbeid sal jy geniet, gclukkig en voorspoedig sal jy wees.

3. Jou vrou is in jou huis soos 'n vrugbare wingerdstok, jou seuns is rondom jou tafel soos jong olyfboompies.

4. Kyk, so word die man geseën wat die Here dien.

5. Mag die Here jou seën uit Sion, dat jy die voorspoed van Jerusalem kan aanskou al die dae van jou lewe.

6. en dat jy jou kindskinders mag sien.

Hierdie vertaling berus op 'n ander vertalingsbeginsel as die ander drie, soos dadelik uit die eerste vers blyk. Die "welgeluksalig" van die Statevertaling is hier vervang met "dit gaan goed met". Die woord dien maak duideliker wat in hierdie verband bedoel word met die Hebrecuse woord yere('), wat op dien of bang wees kan dui. Die Hebreeuse idioom "wat in sy weë wandel" (in die 1933-vertaling) is vervang met "en sy wil doen". Hierdie soort ontbeelding het wel al meermale kritiek ontlok (soos meermale in die proefskrif van I.L. Bekker, 1983). Wat wel opval, is dat die krag van die bevestigende partikel van vers 2 in die vertaling heeltemal verlore gaan, terwyl die 1933-vertaling dit behou het, weens die gebondenheid aan die grondteks. Die twee vertalings stem wel ooreen ten opsigte van die vrou in die huis in vers 3 en die wens en daaropvolgende gevolgsinne in vers 5 en 6 - Gesenius en Brown, Driver en Briggs is nog nie heeltemal verouderd nie! Mcrkwaardig is dat hierdie vertaling van 1979 nog die "kindskinders" van die Statevertaling handhaaf, pleks van die normale "kleinkinders" in vandag se omgangstaal. Wat verder vasstaan, is dat die 1979-vertaling in Psalm 128 in nog makliker Afrikaans vertaal is, maar die verklaring wat aan die 1933-vertaling ten grondslag lê, hoef daarvoor geen tree terug te staan nie - $\mathrm{en}$ is in vers 2 selfs beter!

Natuurlik is die opmerkings oor een kort Psalm nie genoeg om aan al vier die vertalings reg te laat geskied nie, maar dit is genoeg om te wys dat die 1933- 


\section{Van Rooy}

vertaling nog steeds waarde het en dat dit, gelees saam met die 1979-vertaling, God se Woord duidelik tot ons laat spreek. Die manne van 1933 se monument slaan nog steeds - en daarvoor weerklink die "Baie dankie" nog steeds.

\section{BIBLIOGRAFIE}

ALAND, K. e.a. 1975. The Greek New Testament '. New York: United Bible Societies.

ARNDT, W.F. \& FW Ginrich. 1974. A Greek-English Lexicon of the New Testament and other early Christian literature, Chicago: University press.

BLKKER, J.I.. 1983. Job, Hebreeuse poësie en Bybelvertaling (Ongepubliseerde proefskrif, PU vir CHO.)

BROWN, F., S.R. Driver \& C.A. Briggs. 1974. A Hebrew and English lexicon of the Old Testament. Oxford: Clarendon press.

DEKKER, G. \& J.L. de Villiers. 1977. J.D. du Toit (In Suid-Afrikaanse Bibliografiese Woordeboek, III: 260-264).

DREYER, J.G.M. 1939. In memoriam dr. H.C.M. Fourie. Die Hervormer XXCIII/54: 1-3, 30 Augustus.

DU PLESSIS, J. 1929. Die vier evangelies in Afrikaans. Het Zoeklicht, 7: 248-253).

DU TOIT J.D. 1916. Bybelvertaling VII. Het Kerkblad, 357: 2-3, 1 September.

DU TOIT, J.D. 1939. Wyle dr. Fourie. Die Hervormer, XXVIII(54): 19-21.

ENGELBRECHT, S.P.E. 1940. Dr. H.C.M. Fourie. Almanak vir die N.H. kerke, 42,3 .

GESENIUS, W., E. Kautzsch en A.E. Cowley. 1966. Gesenius' Hebrew grammar ${ }^{2}$. Oxford: Clarendon press:

GREENLEE, J.H. 1967. Introduction to New Testament textual criticism. Grand Rapids: Eerdmans. 
Hulde aan ou vertalers

GROENEWALD, E.P. 1969. Die Nuwe Bybelvertaling. Tydskrif vir Ceesteswetenskappe, 9(3) en (4): 193-207.

GROENEWALD, E.P. 1970. Die aktualiteit van 'n nuwe Afrikaanse Bybelvertaling. Nederduits Ciereformeerde Teologiese Tydskrif, 11: 209-219.

JORDAAN, G.J.C. 1975. Die bronne waaruit die Nuwe Testament van die Afrikaanse Bybel vertaal is. (MA-verhandeling, $\mathrm{PU}$ vir $\mathrm{CHO}$ ).

KEE1 B.B. 1958. So onthou ek die groot taak. Cereformeerde Vaandel, 27/4: 5-10.

KIES, C.F. 1935. Die Bybelvertalings van ons NG kerk. Dic Soeklig, 13: 3-11. METZGER, M. 1971. A textual commentary on the Greek New Testament. United Bible Societies.

MÖıl.ER, G.S.J. 1974. Prof. B.B. Keet. Die Kerkbode, 126(1): 2, 3 Julie.

NG Kerke. 1975. Jaarboek van die NG Kerke, 126. Preloria.

NIENABER, P.I. 1934. Die geskiedenis van die Afrikaanse Bybelvertaling. Kaapstad: Nasionale pers.

NIENABER, P.J. 1968, J.D. Kestell (In Suid-Afrikaanse Bibliografiese Woordeboek, I: 411-443).

NIENABER, P.J. \& J.A. Heyl. 1961. Die Afrikaanse Bybelvertaling. Kaapstad: Nasionale Boekhandel.

SMIT, A.P. 1981. E.E. van Rooyen (In Suid-Afrikaanse Bibliografiese Woordeboek, IV: 751).

VAN ZYI., A.H. 1967. Bybelvertaling in teorie en praktyk. Tydiskrif vir Geesteswetenskappe, 4(2): 403-15.

VERHOEF. P.A. 1974. In memoriam: Prof. dr. B.B. Keet. Die Kerkbode, 126/1: 3.

WEISS, P.F.D. 1958. Die wenslikheid van die hersiening van die Afrikaanse Bybelvertaling. Tydskrif vir Wetenskap en Kuns, 18(2): 153-159.

WÜRTHWEIN, E. 1979. The text of the Old Testament. Grand Rapids: Eerdmans. 